Volume and Issues Obtainable at Center for Sustainability Research and Consultancy

Sustainable Business and Society in Emerging Economies

ISSN: 2708-2172 \& (E): 2708-2504

Volume 3: Issue 4 December 2021

Journal homepage: www.publishing.globalcsrc.org/sbsee

\title{
Sports Tourism and its Impact on Economic Growth of a Developing Nation
}

*Muhammad Abdullah Idrees, Lecturer, KASB Institute of Technology, Karachi, Pakistan

Munaza Bibi, Lecturer, Bahria University, Karachi, Pakistan

Javeria Naveed, Lecturer, Bahria University, Karachi, Pakistan

Ayesha Khan, Senior Lecturer, Bahria University, Karachi, Pakistan

*Corresponding author's email: idrees@ kasbit.edu.pk

\begin{tabular}{l}
\hline ARTICLE DETAILS \\
History \\
Revised format: Nov 2021 \\
Available Online: Dec 2021 \\
\hline Keywords \\
Economic Growth, Sports \\
Tourism, Mega Sports \\
Events, Infrastructure \\
Investment, Gross Domestic \\
Product.
\end{tabular}

JEL Classification B22, E60, F62

\section{OPEN ACCESS}

\section{ABSTRACT}

Purpose: This research paper investigates the impact of sports tourism on the growth of economy of a developing nation especially India. We have used the time frame from 1990 to 2016 and we have taken all the international events occurred in India during this span of time. The variables included in this research paper include Gross Domestic Product as dependent variable whereas in control variable we have taken Gross Fixed Capital Formation and Labor Force and International Tourism as focus variable. We have also used dummy variable in our regression model where ' 0 ' refers to years in which India has not hosted any mega sports event and ' 1 ' refers to years in which India has hosted any mega sports event.

Methodology: In order to observe the effect of hosting any mega sports events on growth on economy of India, we have used Ordinary Least Square technique.

Findings: In order to observe the effect of hosting any mega sports events on growth on economy of India, we have used Ordinary Least Square technique. With the help of Regression results we can conclude that there is a positive impact of Sports Tourism on Gross Domestic Product and the dummy variable used in our Regression model also found to be significant. After seeing the results, it is suggested to the policy makers and the Indian Government to increase the investment in the infrastructure and also provide number of incentives to the tourist that are going to visit during any mega sports event, perhaps it will also boost the tourism industry in the country which ultimately effect the growth of economy positively.

Implications: There are other areas which should be the focus of the government in future are socio-cultural issues and environmental impacts of hosting a mega sports event.

(C) 2021 The authors, under a Creative Commons AttributionNonCommercial 4.0

Recommended citation: Idrees, M. A., Bibi, M., Naveed, J., and Khan, A. (2021). Sports Tourism and its impact on Economic Growth of a Developing Nation, Sustainable Business and 
Society in Emerging Economiess, 3(4), 617-628.

\section{Introduction}

Sports tourism is considered to be one of the fastest growing segments of the market in the industry of tourism and is gaining increased attention due to its social, economic and cultural impacts on the host countries. It is considered to be a privileged for the developing countries to host mega sports events and since 2008, developing countries have been successfully hosting mega sports events or international competitions including India that hosted major cricket events in the year 1987, 1996, 1997 and 2011, Asian cycling championship in the year 1989, The 7th Asian Senior Free Style Wrestling Championship in the year 1991, the Commonwealth Wrestling Championship in the year 2013 and many other sports events have been hosted by India.

It has been indicated by various literatures that the major economic benefit generated by mega sport events for a host country is from the consumption by the tourists and other visitors during the sports events or increased in the number of the arrivals of the tourists before and after the event. Major sports events can also be a main reason for positive shifting in the demand for tourism on long term basis. Positive shifts can also be measured by the positive shifts in the supply. The demand of the tourists contributed towards subsidizing the production of goods and services and this production has been characterized by the various different advantages of economies of scale.

Figure 01 shows the trend between the chosen variables including Gross Domestic Product, International tourism, number of arrivals, Gross fixed capital formation, and labor force total for the years 1990 to 2016, the data is being selected from the year 1990 because the data for International tourism before 1990 is not available. According to the figure, the relationship between international tourism and GDP is uncertain because as it can be seen from the figure 1 that between years 1990 to 1997, when international tourism increases then GDP decreases, between years 1998 to 2000, Gross domestic product and number of tourist arrivals in India almost moves in a same direction, but again during years 2010 to 2011, when international tourism decreases then GDP increases which shows a negative relationship between the two variables. This relationship will further be observed through regression model by using an OLS technique.

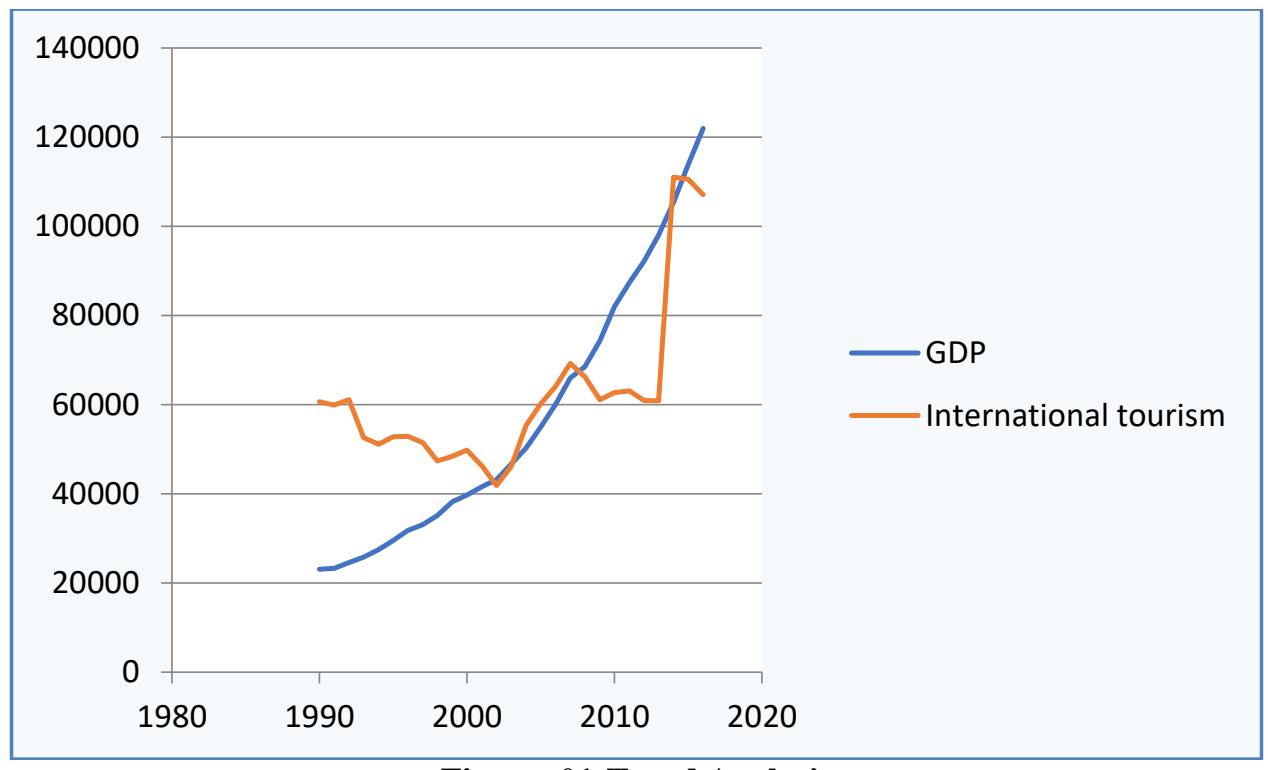

Figure: 01-Trend Analysis

Different research studies indicated that one of the major difficulties in measuring the effects of 
mega sports events on a host region includes lack of knowledge related to the different patterns of the consumption of the visitors as well as the total number of the people that are visiting the region due to the sport event. Due to this lack of knowledge on the consumption patterns of the visitors, it is very important to observe the different effects of the economy of major sports events as well as travel on a host region has been a major activity of the research over the last many years. According to the previous studies, there should be more research work on addressing the different economic and social impacts of the sports tourism for the purpose of understanding the impact of development through mega events on local communities as well as local residents.

Keeping in view the importance of assessing the impact of hosting the mega sports events on the host economy, the objective of this research paper is to analyses the impact of hosting the mega sports events on the economy of India, paying a special focus to the following ten sports events that were hosted by India in different time periods including YMCA International Boxing Championship 1995, Cricket World Cup 1996, Women cricket World Cup 1997, World Cup 2011,The 7th Asian Senior Free Style Wrestling Championship1991,The Commonwealth Wrestling Championship 1997, Women's Cricket World Cup 2013, Hockey World Cup in year 2010, First SAARC International Gymnastic Championship Games in the year 2001, ICC champions trophy in 2006, ICCF world cup in 2003 and Asia cup of Women's hockey team in 1999.

First this paper focuses on the theoretical background in which a model of supply and demand was adopted from the research study of Solberg and Preuss (2007) and this theoretical background is followed by the various different empirical studies that focused on the impact of hosting mega sports events on the nation's economy have been discussed. Next, this paper focused on using an OLS technique in order to analyses the impact of hosting mega sports events on the growth of the host nation's economy by using the Gross Domestic Product as a dependent variable and International tourism, number of arrivals, Gross fixed capital formation, labor force total as independent variables where gross fixed capital formation and labor force are control variables and international tourism is focus variable. We have also used one dummy variable in which ' 1 ' is being assign for the years in which India has hosted mega sports events and ' 0 'for the years in which the nation has hosted no mega sports event, after the research methodology, the results of the regression model have been analyzed.

\section{Literature Review}

In this chapter, we will focus on the various different research studies as well as theories that were proposed by number of researchers and authors for the purpose of analyzing the impact of sports tourism on economic growth of host nations. This research study will focus on different research-based articles on the specific topic from 1994 to 2016.

\section{Theoretical Background}

In this section, economic theories based on sports tourism and its impact on economic growth of host regions or nations will be discussed. According to the research study by Hall (1994) as cited by Frawley (2013), various different mega sports events that were recognized internationally as a hall mark events of the tourism including Olympics Games or the FIFA football World Cup have a great potential to create a significant positive impact on the growth of the tourism industry of the host nation but on the other hand, results of the different empirical studies provide negative or no effect of hosting the mega sports events on the economy of a country depending on the local conditions of the country or region and therefore there is no guarantee that the sports events that have a positive impact on the economy of the nation if they are hosted in one region will have a same positive effect on the economy if hosted in another region of the country.

This study also indicated towards the different ways for bringing improvements in the human 
capital through hosting the sports events including knowledge and skills that can be improved in the service sector of the nation through the training of hospitality for volunteers. Below is a figure that indicated the potential legacy for a host region in hosting a mega sport event, Olympics and the source is modified from the study by Keller (2002).

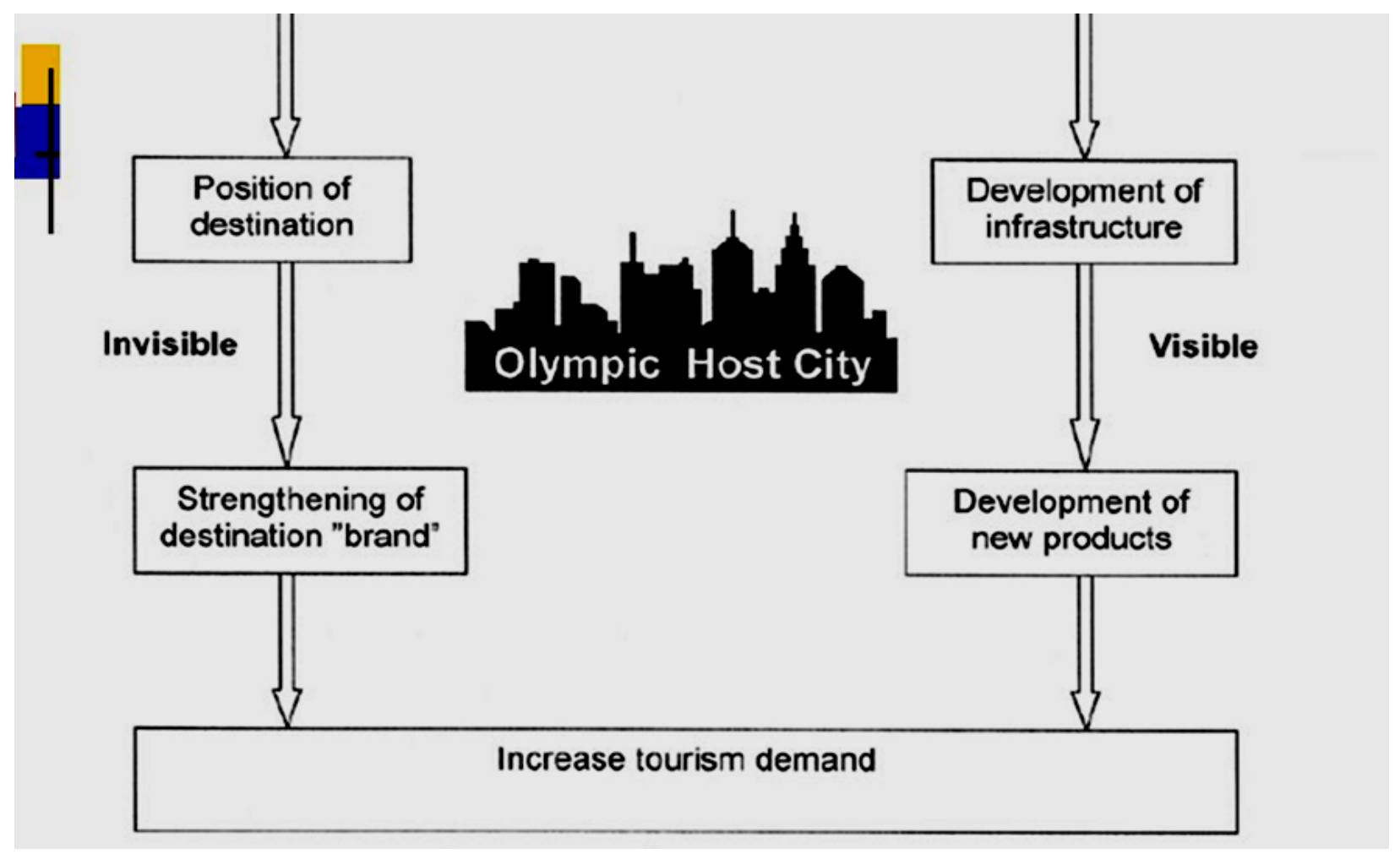

Figure: 02: Potential Tourism Legacy for a Host City or Region Source: Modified from Keller (2002)

The left-hand side of the above figure indicated a destination for tourists that can be measured through mega sports events. Tourist destination aims to attract large number of the tourists to the hosting region and providing suggestions for the policy makers to strengthen the brand for an interesting and strong destination of the tourists. The right-hand side of the figure indicated towards the development of the factors of the location as infrastructure of the tourism including zones of the pedestrians, parks, facilities of the sport, public transportation, freeways, and attraction of the tourists as well as parks and improvement in the airports.

One of the research studies by Solberg and Preuss (2007) made use of an economic model that illustrated the demand of tourist that can affect the production of various different goods and services that also have benefits of the economies of scale. The figure that show this demand and supply model has shown below in which the curves of the demand representing a single product. Mega sports events require number of facilities with these characteristics including infrastructure related to the mega sports events such as different facilities of the sports. Moreover, it also involves investments in the development of the general city including an upgrade of the systems for the transportation (Preuss, 2004).

The demand side of the diagram has been divided into two different parts, one is local residents as (D L) and the other part as tourists ( $\mathrm{D} \mathrm{T}=\mathrm{D} \mathrm{T} \square \mathrm{L}-\mathrm{D} \mathrm{L})$. The marginal cost is considered to be constant and therefore average cost decreases over the interval. The demand of the local residents has been placed below the average cost at each level. The production cannot be measured only on the basis of local demand and this has been changed by the additional tourists 
demand due to the fact that aggregate demand ( $\mathrm{D} \mathrm{T} \square \mathrm{L}$ ) is more than the curve of the average costs in the two intervals Q1 as well as Q2. Therefore, due to the demand of the tourists, local residents can now be able to purchase different goods and services that could be consumed by them only outside the host city or region unless the different products and services has been subsidized.

If there is no price discrimination then tourists and local residents will have to pay the same prices then Q2 represents the highest break-even quantity. Local residents consume quantity Q2L and P2ab represents their consumer surplus. Here producers are not making any profit because their revenues are equal to the cost. Production of various different goods as well as services can generate gains of welfare economics specifically when these products have benefit of economies of scale. These gains can be maximized by using different pricing policies where the price should be equal to the marginal costs and here government should intervene through subsidizing the products otherwise the demand curve can come back to its starting position if the effect of the promotion fades out.

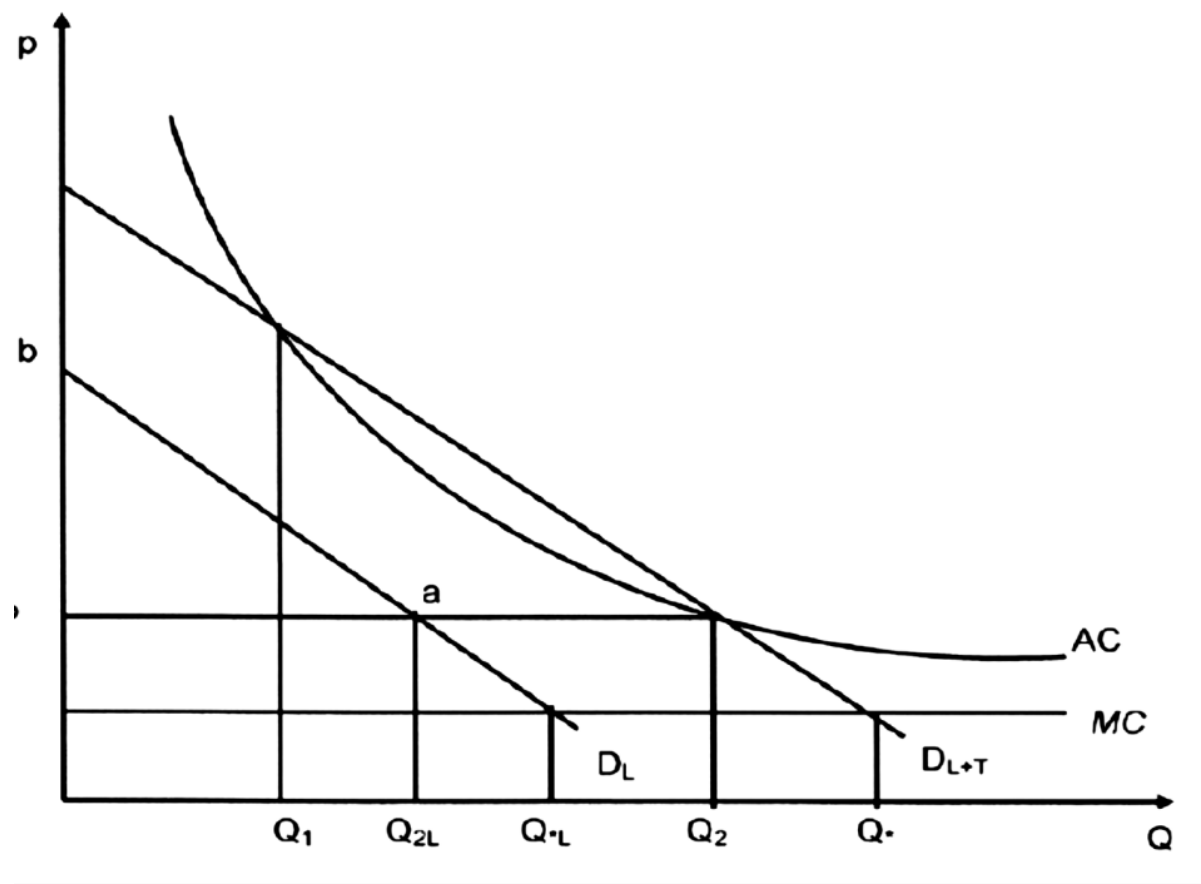

Figure 03: Demand and Supply for Tourism Products Source: Solberg and Preuss (2007)

\section{Empirical Studies}

This section will focus on discussing the different research studies that were written by various different researchers during time period 2001 to 2016 in order to observe the impact of hosting mega sporting events on the economic growth of host nations.

Jones (2001) identified the nature of the social as well as economic impact of hosting the mega sporting events on Wales of the 1999 Rugby World Cup. The author has reviewed the different literatures on same subject and indicated that mega sports events have significant social impacts as any event can put a stress on property markets as well $\mathrm{s}$ on local housing but on the other hand, it was also be noted that these events have significant positive social impact because such events can also contribute towards developing sense of worth of the community. The author concluded that hosting the mega sports events was a success for the host nations but still the economic benefits of hosting the event are uncertain. 
Bohlmann and Heerden (2005) focused on examining the effect of pre event phase expenditure on hosting the FIFA World Cup 2010 on the economy of South Africa. In this phase, expenditures representing the construction as well as improvement of the infrastructure required for hosting a mega event. The authors had used Computable General Equilibrium (CGE) model which was particularly developed for the South African economy. The research paper also used a model of UPGEM which is specially designed for the comparative static simulations. The two important outcomes that were considered by the author was the impact on employment as well as GDP and therefore the author had decided to use a modified version of the short run closure in order to generate the results.

Matheson (2006) gave an overview of the economics of sports events and also provide review of the existing literature that focused on the same topic. The author had observed the effect of mega sporting events of the World on local, national as well as regional economies. The author recommended that there are different ways in order to maximize the net benefits of hosting the mega sports events in host regions such as, through limiting the expenditures of the new infrastructure in order to compensate the cost of an event that will in turn increases the benefits of the mega events. Secondly, the local officials of the host regions should understand that hosting many small events may generated much large net benefits as compare to the strategy that lead to the large mega events because crowding out is less likely to occur in small events as compare to the large events, therefore instead of focusing on hosting mega events, they should also host smaller events in the region that will increase the net benefits of the hosting economy.

Gratton, Shibli and Colemon (2006) observed the economic impacts of the major sporting events in the world. The authors had reviewed total ten sporting events in the United Kingdom. Initially the authors had reviewed the literature that focused on the economic importance of the big events. The 2002 World snooker Championship were studied by the authors as a part of sport funded research project of the United Kingdom for the purpose of estimating the economic impacts of the major events. The total ten events studied by the researchers were conducted by using the same methodology. Therefore, this gave the added value of dataset in which all the events can be compared. The methodology used in this paper in order to analyses the economic impact of the events was divided into total ten stages. The authors had used instrument of questionnaire in order to interview the main interest group at the major event. The collected data was then analyzed by using a statistical software package as well as spread sheets to calculate the additional expenditures in the economy of the host country.

Humphreys and Prokopowicz (2007) attempted to assess the impact of mega sports events in transition economies including EURO 2012 in Poland and Ukraine where Poland and Ukraine would be the finalist to host the Union of European Football Association, Football championship in the year 2012. The authors had focused on these two countries because they represent an interesting as well as important contrast to the typical regions that are engaged in hosting the sports mega events in the political, cultural and economic terms. Both of these economies are considered to be transition economies whereas Poland is also a member of European Union. The authors had done cost and benefit analysis in order to assess the economic impact of the major sport event and most of the costs of hosting the football championship would be driven by the requirements of the UEFA for a host area.

Solberg and Preuss (2007) analyzed the impact of tourism of hosting major events of the sports in which the authors pay special attention to the long-term impact of hosting such events on the economy. Initially the authors had focused on the structural requirements of the host cities. The authors presented some empirical results as well as long term effects in order to illustrate that how some factors can influence the long-term impacts. According to the empirical results, a host city put special focus on three areas including the city development, the infrastructure that is 
required for the event as well as the infrastructure that is not included in the long-term development plan of the city. The results also suggested that there are three ways through which human capital can be obtained through hosting an event including, skills as well as knowledge can be upgraded in the industries through providing hospitality training to the volunteers, the skills that are required for securing a safer environment can also be enhanced.

Kavetsos and Szymanski (2008) examined the impact of hosting the mega sport events on the national wellbeing or examine the "feel good factor". The authors had used the data on selfreported life satisfaction for total twelve countries of the Europe in order to test the effect of hosting the mega sports events on happiness. The data covered three important events including the Olympic Game, the FIFA World Cup and the UEFA European Championship. The research study considered two hypotheses, first hypothesis is that the success of the athletes of the nation's produces the increase in happiness among the citizens of the nation and second hypothesis is that simply representing a host nation that produces an increase in the happiness among the local residents of the hosting nations. The authors used pooled cross section data of the surveys which reported happiness in the different countries of Europe from the total 30 years.

Giraud (2014) explored the effect of mega sports events on employment and more specifically the research paper focused on demonstrating that the Football World cup of 1998 had a positive impact on the employment generation of the host regions. Moreover, the research paper indicated differences between the host areas where the employment of some areas or regions had been affected by the employment of other areas. The authors initially analyzed the effect on employment generation in the host region by making use of a Difference in Difference approach which was a method employed for the purpose of measuring the changes generated by a specific treatment or event. In this paper, the treatment group would be having hosted the Football World Cup whereas the control group included other regions. There are total two indicators that were based on time dimension ' $t$ ' and spatial dimension ' $i$ '. Variable $x 1$ would take the value 1 if ' $i$ ' represented a treatment group and would take value 0 when it represented a control group. On the other hand, $\mathrm{x} 2$ would take the value 1 if ' $\mathrm{t}$ ' is greater than 1997 otherwise it would take ' 0 '. Other variable $\mathrm{x} 3$ represented an interaction between both types of effects and would take value 1 when $\mathrm{x} 1$ and $\mathrm{x} 2$ would be equal to 1 .

Obinna and Onwe (2016) focused on the critical analysis of the various economic impacts of hosting the mega sports events on hosting nations which is considered to be one of the main issues in the development of the sports tourism. The findings of this research paper are basically based on the various different examples that were drawn from the different literature on mega sports events. This paper indicated that although the mega events brought huge financial benefits to the hosting nations but on the other hand, economic impact of hosting such events is not always found to be positive as the predicted economic benefits. The author further observed that hosting mega events sometime also contributed towards huge financial deficit to the host areas while provide benefits to some other sectors of the economy.

In this paper we have established a following hypothesis;

H0: Sports tourism has a significant positive impact on economic growth of a host nation

\section{Research Methodology}

In this section, we have discussed the research model for this research study. The data that has been used for this research study is basically time series data that covers years from 1990 to 2016. The data for dependent as well as independent variables were taken from data bank of World Bank, and OECD data. An Ordinary Least Square technique has been used in order to examine the impact of sports tourism on the economic growth of host nation specifically India. For regression model, this research paper focused on using cob- Douglas production function in 
which we have two control variables which are labor force and gross fixed capital formation and one is focus variable which is international tourism. This research paper have also used a dummy variable for which we assigned ' 1 ' for the years in which the country had hosted no mega sport event and ' 0 ' for the years in which the nation had hosted mega sports events in their country. This dummy variable is being used in order to observe that whether there is a significant change in the economic growth of India during the years in which it hosted mega sports events or not? The following regression model can be used in this research paper;

$$
\operatorname{LogGDP}=\beta 1+\beta 2 \log I T+\beta 3 \log L F+\beta 240 g C F+\beta 5 D u m+u
$$

Where the 'GDP' represents gross domestic product, 'IT' represents international trade, 'LF' stands for labor force, ' $\mathrm{CF}$ ' for capital formation and 'Dum' is indicating a dummy variable in which ' 0 ' is being assigned for the years during which India has hosted no mega sports events and ' 1 ' for the years during which it has hosted mega sport events. Annual data from 1990 to 2016 has been used and the data has been taken from data bank of World Bank and OECD data.

\section{Estimation and Results}

This section will focus on discussing the estimated methods as well as results of our regression model for the purpose of observing the impact of hosting mega sports events on growth of Indian economy.

\section{Stationary Test}

As our data is time series data therefore, we have used Augmented Dickey Fuller test in order to check that whether our variables are stationary or not; the results of ADF test are given in table 1 below:

\begin{tabular}{|c|c|c|c|c|}
\hline \multirow[t]{3}{*}{ Variables } & \multicolumn{2}{|l|}{ ADF Test (at levels) } & \multicolumn{2}{|l|}{$\begin{array}{l}\text { ADF Test (first } \\
\text { Difference) }\end{array}$} \\
\hline & with Constant (c) & $\begin{array}{l}\text { with constant \& trend } \\
(\mathbf{C \& t})\end{array}$ & with Constant (c) & $\begin{array}{l}\text { with constant \& } \\
\text { trend }(C \& t)\end{array}$ \\
\hline & $\begin{array}{lll}\text { ADF } & \text { test } & \text { statistics } \\
\text { (prob) } & & \\
\end{array}$ & ADF test statistics (prob) & $\begin{array}{l}\text { ADF test statistics } \\
\text { (prob) }\end{array}$ & $\begin{array}{l}\text { ADF test statistics } \\
\text { (prob) }\end{array}$ \\
\hline GDP & 1 & 0.999 & 0.001 & 0.0042 \\
\hline Capital & 0.9957 & $\mathbf{0 . 4 5 9 3}$ & 0.0014 & 0.008 \\
\hline Labour & 0.619 & 0.7948 & 0.0013 & 0.0037 \\
\hline Int.tourism & 0.8977 & 0.7747 & 0.0013 & 0.0028 \\
\hline
\end{tabular}

Table 01: Augmented Dickey Fuller Test

*The critical value for augmented dickey fuller test with intercept at 5\% level of significance is -2.998064 and with intercept and trend is -3.622033 . 
The results of above table indicated the presence of non-stationary in all the selected variables at levels with ADF test. First, we have checked that whether variables are stationary or nonstationary with intercept and then with intercept and trend in which the null hypothesis claims that variables are non-stationary and alternative hypothesis claims that variables are stationary. According to the results of ADF test at levels, the p-values of all the variables are higher than 5\% and let the author to accept the null hypothesis according to which, all the variables are nonstationary. Then in order to make all the variables stationary, the author has taken first difference of the variables. At first difference, the ADF test statistics is greater than critical values and hence we can now reject the null hypothesis that variables are non-stationary. Now after taking the first difference, the data is said to be stationary and hence the estimates of the regression model are not said to be superior.

\section{Ordinary Least Square Test}

Now, we have used OLS technique by using E-Views software in order to observe the impact of sports tourism on economic growth of India. The results of our regression model are given in table 2 below:

\begin{tabular}{|l|l|l|l|l|}
\hline Variables & Coefficient & T.statistics & Probability & VIF \\
\hline Constant & -38.17490 & -11.9348 & 0. & --- \\
\hline Log LABOUR & & & & \\
\hline Log TOURISM & 2.887596 & 14.12511 & 0 & 3.64 \\
\hline DUM & $\mathbf{0 . 6 9 7 2 2 3}$ & 6.445607 & 0 & 3.94 \\
\hline Adjusted R-squared & $\mathbf{0 . 0 9 4 7 1 3}$ & 2.268157 & 0.0330 & 1.51 \\
\hline F-statistic & 0.961364 & & & \\
\hline Durbin-Watson statistics & 216.6513 & & & \\
\hline
\end{tabular}

Table 02: Ordinary least Square Test

The results of table 02 indicated that labor and international tourism has significant positive effect on the Gross domestic product of India. Our results are evident from the report of World Tourism Organization (2010) according to which, due to the increase in total number of tourist arrivals in a country as well as due to the increased investment in the development for tourism industry, international tourism has become an important source for the economic progress because it contributed towards creating new employment opportunities, developing infrastructure and earning of revenues through export of local goods and services. Therefore, it can be said that the sector of tourism has contributed towards generating revenue as well as creating new jobs in most of the developing countries. On the other hand, international tourism can also generate foreign exchange earnings in the country that contributed towards sustainable development as well as economic growth of the developing nations.

Research study by Balaguer and Cantavella- Jorda (2002) indicated that international tourism may be an important reason of increasing of income in different ways such as, it enhances the efficiency through increasing competition between the local industries as well as the industries that correspond to the other different destinations of the tourists and it also may makes the 
utilization of economies of scale of local firms possible. Our positive and significant results between tourism and gross domestic product are also evident from the research study by Kreishan (2010) in which the author observed the relationship between economic development as well as growth and tourism earnings. According to the findings of his study, tourism earnings and economic development of a nation are significantly positively related with each other in the long run. According to the research studies by Tang and Tan (2015), Hye and Khan (2013), Jalil, Mahmood, and Idrees (2013), tourism has a positive effect on the economic growth of a nation.

On the other hand, table 02 also shows a significant positive value of Dummy variable which means that sports tourism or hosting mega sports events contributed towards stimulating the growth of India's economy. Thus, we accept our null hypothesis that Sports tourism has a significant impact on economic growth of a host nation. According to the research study by Getz (2016), sometimes small as well large events both have significant impact on the economy of developing countries due to the increased number of tourists in a country that generate revenue as well as due to various other economic benefits. Findings of another research study by Giampiccoli, Lee \& Nauright (2015) in which they focused on the impact of hosting FIFA World cup 2010 on economic growth of South Africa indicated that, this mega sports event had been a success for South Africa because it contributed towards boosting the tourism industry of the country in short term between June 2010 to July 2010. This mega sports event was found to be sustainable and less costly as well as brought mega impact on the economy of the host region and nation.

We have also checked the existence of auto correlation in our model through Hackman test and problem of multicollinearity trough VIF test. Values of VIF for all variables are less than 10 which mean there is no multicollinearity in our model. Hackman test also shoes the absence of autocorrelation in our regression model.

\section{Conclusion and Recommendations}

This research paper focus on observing the impact of hosting mega sports events on the economic growth of a host nation specifically India. For this purpose, we have taken time series data from year 1990 to year 2016 and observed the impact of 12 mega sports events on Indian's economy including, YMCA International Boxing Championship 1995, Cricket World Cup 1996, Women cricket World Cup 1997, World Cup 2011, The 7th Asian Senior Free Style Wrestling Championship1991,The Commonwealth Wrestling Championship1997, Women's Cricket World Cup2013, Hockey World Cup in year 2010, First SAARC International Gymnastic Championship Games in the year 2001, ICC champions trophy in 2006, ICCF world cup in 2003 and Asia cup of Women's hockey team in 1999. The research paper have discussed various research studies as well as economic theories that that focused on the impact of hosting mega sports events on the nation's economy.

We have used an OLS technique for the purpose of analyzing the impact of hosting mega sports events on the economic growth of the host nation in which Gross Domestic Product is a dependent variable and International tourism, number of arrivals, Gross fixed capital formation, labor force total are independent variables. We have also used one dummy variable in which ' 1 ' indicated the years in which India has hosted mega sports events and ' 0 ' indicated the years in which the nation has hosted no mega sports event.

Results of our regression model indicated that international tourism is positively related with the gross domestic product of India and on the other hand, dummy variable is found to be significant in our regression results which shows that hosting mega sports events contributed towards the growth of nation's economy or sports tourism has a significant positive impact on the economic growth of India. Various different research studies indicated that international tourism is an important source of generating revenues and employment in the host nation through increased 
foreign exchange earnings and therefore it can be said that sports events may have a significant impact on the economic growth of a host nations' economy.

The government should first consider the necessary requirements of the sports infrastructure and should avoid investing on unnecessary infrastructure in order to reduce the cost of mega sports events. The government of India needs a transparent as well as clear assessment of the significance of the mega sports events and also to implement effective, sustainable and efficient planning in order to avoid huge costs of the events. Moreover, sports tourism as well as sector of the different events should be examined efficiently through comparison and also to play their key role in the planning of tourism and economic development in future. Although ministry of Youth Affairs and Sports in India has been efficiently engage in making effective policies to boost sports tourism including policies regarding infrastructure development, manpower development, marketing and investment policies but it should focus more to increase investment in improving the infrastructure including rail and railways networks that can not only facilitate the local people but attract foreigners to visit India.

This research study highlights the economic impact of sports tourism, it is to be suggested that future research should focus on measuring the socio-cultural as well as environmental impact of the sports tourism on India. Further research should examine that how sports tourism creates positive and peaceful nation of the country and how it contributed towards increasing the level of pollution in the host region?

\section{References}

Adnan Hye, Q. M., \& Ali Khan, R. E. (2013). Tourism-led growth hypothesis: a case study of Pakistan. Asia Pacific Journal of Tourism Research, 18(4), 303-313.

Balaguer, J., \& Cantavella-Jorda, M. (2002). Tourism as a long-run economic growth factor: the Spanish case. Applied economics, 34(7), 877-884.

Baumann, R., \& Matheson, V. (2013). Infrastructure investments and mega-sports events: Comparing the experience of developing and industrialized countries.

Bohlmann, H. R., \& van Heerden, J. H. (2005). The impact of hosting a major sport event on the South African economy. Journal of Tourism, 26(4), 595-603.

Chalip, L., \& Costa, C. A. (2006). Building sport event tourism into the destination brand: Foundations for a general theory.

Frawley, S. (2013). Sport participation legacy and the hosting of mega-sport events. Exploring the social impacts of events. New York: Routledge, 97-110.

Getz, D., \& Page, S. J. (2016). Event studies: Theory, research and policy for planned events. Routledge.

Giampiccoli, A., Lee, S. S., \& Nauright, J. (2015). Destination South Africa: Comparing global sports mega-events and recurring localized sports events in South Africa for tourism and economic development. Current Issues in Tourism, 18(3), 229-248.

Giraud, T. (2014). Economic impacts of hosting a major sporting event: Did the 1998 FIFA World Cup have positive impacts on employment?

Gratton, C., Shibli, S., \& Coleman, R. (2006). The economic impact of major sports events: a review of ten events in the UK. The Sociological Review, 54(s2), 41-58.

Humphreys, B. R., \& Prokopowicz, S. (2007). Assessing the impact of sports mega-events in transition economies: EURO 2012 in Poland and Ukraine. International Journal of Sport Management and Marketing, 2(5-6), 496-509.

Jalil, A., Mahmood, T., \& Idrees, M. (2013). Tourism-growth nexus in Pakistan: Evidence from ARDL bounds tests. Economic Modelling, 35, 185-191.

Jones, C. (2001). Mega-events and host-region impacts: determining the true worth of the 1999 Rugby World Cup. International Journal of Tourism Research, 3(3), 241-251.

Kasimati, E. (2003). Economic aspects and the Summer Olympics: a review of related research. 
International journal of tourism research, 5(6), 433-444.

Kavetsos, G., \& Szymanski, S. (2010). National well-being and international sports events. Journal of Economic Psychology, 31(2), 158-171.

Keller, P., Breiter, M., Duc, N., \& Salamin, F. (2002). Sport and tourism. World Trade Organization.

Malfas, M., Houlihan, B., \& Theodoraki, E. (2004). Impacts of the Olympic Games as megaevents. ICE.

Matheson, V. (2006). Mega-Events: The effect of the world's biggest sporting events on local, regional, and national economies.

Matheson, V. A., \& Baade, R. A. (2004). Mega-sporting events in developing nations: playing the way to prosperity? South African journal of economics, 72(5), 1085-1096.

Matheson, V., \& Baade, R. (2006). Going for the Gold: The Economics of the Olympics (No. 1605).

Peeters, T., Matheson, V., \& Szymanski, S. (2014). Tourism and the 2010 World Cup: Lessons for developing countries. Journal of African Economies, 23(2), 290-320.

Solberg, H. A., \& Preuss, H. (2007). Major sport events and long-term tourism impacts. Journal of sport Management, 21(2), 213-234.

Tang, C. F., \& Tan, E. C. (2015). Does tourism effectively stimulate Malaysia's economic growth?Tourism Management, 46, 158-163.

The World Tourism Organization (2010), Tourism Highlights, 2010 Edition.

Wise, N., \& Perić, M. (2017). Sports tourism, regeneration and social impacts: New opportunities and directions for research, the case of Medulin, Croatia. In Tourism in the City (pp. 311320). Springer International Publishing. 